\author{
AgNiESZKA M. BARWICKA \\ Uniwersytet im. Adama Mickiewicza \\ w Poznaniu
}

\title{
ŚWIADOMOŚĆ KONSUMENCKA MŁODZIEŻY
}

\begin{abstract}
Barwicka Agnieszka M., Świadomość konsumencka młodzieży [Consumer Awareness of Young People]. Studia Edukacyjne nr 50, 2018, Poznań 2018, pp. 413-423. Adam Mickiewicz University Press. ISSN 1233-6688. DOI: 10.14746/se.2018.50.27
\end{abstract}

Young people face many choices in modern times. The flood of information means that a young person must make many decisions in line with their knowledge and hierarchy of values. Since the development of media and technology has become very important in the everyday life of average teenagers, brands presenting their products reach them through all possible avenues. Regardless of whether teenagers want it or not, they have to face the impact of advertising and select content they find useful. The article presents the results and interpretation of the results of own research conducted on youth.

Key words: consciousness, consumer, youth

\section{Wprowadzenie}

W opinii społecznej istnieje przekonanie, że młodzież nie jest świadoma, jak reklamy i marki oddziałują na decyzje konsumenckie. Manipulacja młodymi konsumentami odbywa się za pomocą mediów, które wykorzystują reklamy zarówno te prezentowane w sposób jawny jak i ukryty. Dochodzi do tego, że w okresie dojrzewania i towarzyszącemu temu kryzysowi tożsamości, młodzi ludzie stają się pożądaną grupą konsumentów dla twórców reklamowych. Świat wartości, który budują, budząca się dopiero moralność, krytycyzm i umiejętność podejmowania właściwych wyborów może okazać się decydująca podczas dokonywania wielu decyzji konsumenckich. Ich świadomość konsumencka stała się dla mnie na tyle interesującym tematem, że postanowiłam przyjrzeć mu się bliżej i przeprowadzić badania na interesującej mnie grupie młodzieży. Mam bowiem świadomość, że jest to interesująca dla rynku reklamowego grupa, która z jednej strony generuje olbrzymie przychody, z drugiej - ze względu na swoją różnorodność pokoleniową - jest 
ciekawą grupą do działania dla wszystkich osób zajmujących się marketingiem reklamowym.

Z badań Matego Rocznika Statystycznego Polski 2018 wynika, że osoby do 19 roku życia, w 2016 roku stanowiły 20,1\% populacji. Wraz z upływającym czasem odsetek ten maleje ze względu na niż demograficzny. Niepokojącym zjawiskiem wpływającym na niski przyrost populacji jest wzrost liczby samobójstw wśród nastolatków. Młodzi ludzie między 15-19 rokiem życia w okresie od 2010 - 2017 roku nie radzą sobie ze swoją tożsamością i decydują się odebrać sobie życie. W ostatnich latach liczba ta wzrosła o ponad 200\%. Może to świadczyć o tym, jak bardzo młodzi ludzie czują się zagubieni w świecie, w którym coraz większe znaczenie ma konsumpcjonizm przedkładany nad wartościami, etycznym i moralnym zachowaniem, nawiązywaniem głębokich relacji społecznych, czy podążaniem za autorytetami.

Rousseau powiedział, że każdy wiek, każdy stan życia osiąga odpowiednią doskonałość, pewien rodzaj właściwej mu dojrzałości. Autor sugeruje, że taki powinien być okres dorastania, czyli startu w samodzielne życie osobiste i społeczne. Okres ten znajduje się pomiędzy czasem dzieciństwa a dorosłością ${ }^{1}$, czyli podczas przemiany dziecka $\mathrm{w}$ osobę dorosłą. $\mathrm{W}$ tym okresie następuje weryfikacja dotychczasowych doświadczeń w świetle nowych, powstają też struktury, które zmieniają znaczenie tych nabytych wcześniej².

Zanim bowiem dorastający odnajdzie siebie i odkryje, jaki jest i co potrafi, a czego nie, zanim odkryje jak widzą go inni, będzie podejmował liczne próby, aby się o tym przekonać, będzie ryzykował i popełniał błędy, bo bez tego cały ten proces nie może wypełnić swojej misji, jaką jest samodzielne skonstruowanie własnej tożsamości ${ }^{3}$.

Dlatego istotna jest obserwacja i badania zachowań konsumenckich młodzieży; w dużej mierze dają nam bowiem obraz tego, jak bardzo podatny na wpływ reklam jest młody człowiek i jak bardzo uformowana jest już jego tożsamość.

\section{Przegląd literatury}

Młodzież przez bycie częścią społeczeństwa przyswaja informacje, normy i wartości, zarówno w sposób świadomy, jak i nieświadomy. Buduje też swoją tożsamość, czyli

\footnotetext{
${ }^{1}$ A. Brzezińska, Społeczna psychologia rozwoju, Warszawa 2005, s. 217-222.

2 J. Strelau, D. Doliński, Psychologia, t. 2, Gdańsk 2008, s. 233.

${ }^{3}$ M. Bardziejewska, A. Brzezińska, Sz. Hejmanowski, Osiagnięcia rozwojowe i zagrożenia dla rozwoju w okresie dorastania [w:] Dzieci i młodzież wobec agresji i przemocy, red. A. Brzezińska, E. Hornowska, Warszawa 2004, s. 91.
} 
świadomość własnej spójności w czasie i przestrzeni, w różnych okresach życia, w sytuacjach społecznych i pełnionych rolach, a także świadomość własnej odrębności, indywidualności, niepowtarzalności ${ }^{4}$.

Młody człowiek jest często nieświadomy oddziaływania i wpływów społecznych. W przeciwieństwie do procesu socjalizacji, wychowanie odgrywa nieco inną rolę - jest świadome i ma konkretny cel. Często powodem jest brak paradygmatów i oddziaływań wychowawczych ${ }^{5}$, dlatego wychowanie powinno być bardziej elastyczne, dające możliwość negocjacji i kompromisów. Młodzież należy tak kształtować, aby świadomie podejmowała wybory odnośnie własnego „ja”. Nastolatki chcą mieć wpływ na kształtowanie swojej tożsamości, chcą same budować swoje marzenia i życie, chcą wybierać, jakie ich potrzeby mają być zaspokojone w danym momencie. Pojawia się pragnienie poznawania wszystkiego co ich dotyczy oraz interesuje. Trzeba pamiętać, że młodzież odczuwa wszystko silniej i mocniej niż dorośli. Nie jest jeszcze przyzwyczajona do tak dużych emocji ${ }^{6}$. Socjalizacja i wychowanie to dwa odmienne procesy. Jeden pełen ekscytacji, świadomy, drugi - pełen przyjemności, nieuświadamiany. Dla wielu ludzi stają się one jedynym realnym doświadczeniem ${ }^{7}$. Oba światy się przenikają i czerpią wzajemnie budując tożsamość współczesnego nastolatka. Takiego nastolatka o zmiksowanej tożsamości można nazwać homixem ${ }^{8}$.

Uznanym środkiem socjalizacji jest reklama9 . Doliński stwierdza, że (konsument) jest istotą nieracjonalną ${ }^{10}$, niezależnie od tego czy ma bezpośredni dostęp do pieniędzy czy pośredni. Manipulacja za pomocą chwytów marketingowych staje się niezbędna dla przedsiębiorców. Dla klientów nie jest bowiem ważna ilość wydawanych pieniędzy, natomiast istotne jest, aby mieli oni poczucie, że zaoszczędzili. Kupony, talony i rabaty są jednymi z chwytów marketingowych, które pozwalają wybić się przedsiębiorstwom spośród wielu marek oferujących swoje produkty na dostępnym dla konsumenta rynku. Aby dostosować się do młodzieży, przedsiębiorcy wykorzystują tak zwanych influencerów, czyli osoby znane z mediów, o silnym wpływie oddziaływania na pewne grupy społeczne do sprzedaży swoich produktów. Reklamodaw-

${ }^{4}$ M. Melchior, Społeczna tożsamość jednostki (w świetle wywiadów z Polakami pochodzenia żydowskiego w latach 1944-1955), Warszawa 1990.

5 A. Zawada, Reklama a socjalizacja społeczna dzieci i młodzieży, [w:] Media i edukacja w aspekcie globalizacji, red. A.W. Mitos, przy współudziale Z. Gajdzicy, Cieszyn 2003, s. 218.

${ }^{6}$ J.C. Dobson, Przygotowanie do dojrzałości, Warszawa 1993, s. 103.

7 Z. Melosik, T. Szkudlarek, Kultura, tożsamość i edukacja - migotanie znaczeń, Kraków 1998, s. 16.

8 J. Kurzępa, Zagrożona niewinność, Kraków 2007, s. 12.

9 A. Jawłowska, Reklama jako przekaz wartości, [w:] Kultura w procesie zmiany, red. A. Jawłowska, G. Woroniecka, Olsztyn 2003, s. 48.

10 D. Doliński, Psychologiczne mechanizmy reklamy, Gdańsk 2005, s. 160. 
cy kumulują swoją energię wokół autorytetów młodych ludzi takich, jak na przykład FitLovers ${ }^{11}$, którzy nie tylko mają swój kanał na YouTubie, ale również prowadzą biznes, mający dostarczać produkty młodym konsumentom. Pojawia się zależność: im większe zaangażowanie influencera, tym większe grono jego obserwatorów i marka zyskuje więcej klientów. Wynika to z tego, że młodzi konsumenci są lojalni i korzystają z produktów swoich influencerów, łatwo, chętnie i szybko zapamiętując promowane przez nich marki. Aby zwrócić uwagę klienta, pozyskać i zbudować jego zaufanie do marki, przedsiębiorcy wydają zawrotne sumy pieniędzy. Chcą by klient żył ich marką, by przekazywał o niej pozytywne informacje dalej, wśród swoich rówieśników, osób znanych, ale i tych spotkanych przypadkowo, na przykład na portalach społecznościowych. Najlepszą reklamą jest przecież informacja o marce od osoby, z której zdaniem się liczymy. Jeśli marka nie zdobyła wiarygodnej opinii, nie zdobędzie jej bez wsparcia idoli. Klienci muszą kojarzyć markę i mieć korzyści z jej kupowania. Aby tak się stało, coraz częściej przedsiębiorstwa utrzymują stale swoich klientów przy pomocy influencerów. Najlepsze firmy przekonują konsumentów do zakupów świadomych i aktywnych, w ukryciu pracując nad przywiązaniem klienta do marki tak, aby nie zorientował się, że w dużej mierze decyzje jakie podejmuje są zmanipulowane. Młody człowiek musi mieć świadomość, że nabywając dany towar, coś zyskał. Jeszcze lepiej, kiedy klient nie tylko pragnie jakiegoś produktu, ale też jego zakup oraz posiadanie łączy z nagrodą i wyróżnieniem. Jego nabycie daje marce możliwość zbudowania solidnego i pozytywnego wizerunku własnej firmy oraz przywiązania klienta do produktu, marki i firmy nawet na dłuższy czas.

Kulturowe wirowanie, czyli mieszanie się kultur staje się dla nastolatków naturalne i normalne. Dzięki multimediom nasze codzienne kontakty stały się szybkie, szerokie, powierzchowne, ale też bardzo często anonimowe. Nastolatki wykazują się podejrzliwością i sceptycyzmem w świecie realnym, ale aż nadmierną ufnością w Sieci, nie zauważają więc, że ich ulubione medialnie postaci są często dobrze opłacanymi przez firmy i przedsiębiorstwa osobami reklamującymi konkretne produkty, często w sposób mało uczciwy, bo nie informujący o tym swoich odbiorców. Treści reklamowe przemycają często mimochodem i ukradkiem tak, aby ufna młodzież nie zwróciła na to uwagi. YouTuberzy pod hasłem challenge przyciągają uwage odbiorcy do zadania, a przy okazji sprzedają produkt, który młodzieży nie jest potrzebny. Przykładem takich produktów może być na przykład slime challenge, gdzie twórcy wytwarzają z dużej ilości produktów (w tym kleju) masę, która ma właściwości rozciągające. I w taki sposób można sprzedać klej w sporych ilościach, który dotychczas młodym ludziom nie był potrzebny. Utożsamianie się i po-

${ }^{11}$ FitLovers - twórcy internetowi prowadzący vlog lifestyle'owy. 
wtarzanie czynności wykonywanych przez influencerów pozwoli producentom dotrzeć do konsumentów z każdym produktem.

Marka musi spełniać wszystkie zachcianki młodzieży. Inaczej nie mogłaby istnieć. Kultura konsumencka opiera się na rozwoju kultury współczesnej. Wpływają na nią również nasze decyzje i cały nieograniczony świat konsumencki. Panuje przekonanie, że istniejemy tylko po to, aby wypełniać koszyki w hipermarketach - homoshopping. Jesteśmy konsumentem, który ma za zadanie przyjmować produkty, które są mu oferowane. Jeśli ktoś twierdzi, że ma zaspokojone wszystkie potrzeby, to już wkrótce się przekona, że tak nie jest, że bardzo szybko świat konsumencki wygeneruje nowe, o których nawet nie mieliśmy pojęcia, a które są w stanie i sztucznie wykreować nasz nowy styl życia.

Jeszcze niedawno kultura osobista nie pozwalała wysyłać wiadomości SMS po godzinie 22.00. Współcześnie młodzież jest dostępna 24 godziny i 7 dni w tygodniu. Tak samo jest z produktami wytwarzanymi przez Internet. To, co pojawiło się w nim, dla młodych ludzi jest jak najbardziej realne. Twórcy internetowi mają bardzo duży wpływ na kształtowanie się estetyczne i poznawcze nastolatka ${ }^{12}$. Młodzież otrzymuje obecnie od nich często gotowe rozwiązania. Coraz powszechniejsze jest szukanie pomocy w mediach, zamiast samodzielne zmierzenie się z problemem i próba jego rozwiązania. $\mathrm{Na}$ tej samej zasadzie młodzi ludzie ufają markom (influencerom), które ich nie zawiodły, a podają im właśnie gotowe rozwiązania na dręczące ich problemy i potrzeby, poprzez promowanie pewnych określonych produktów. Wiedząc o tych potrzebach, firma marketingowa może stworzyć idola nastolatków, który pod modnym hasłem "co jest trendy" będzie reklamował konkretne produkty, nie informując wcale, że jest to zwykły product placement.

Współcześnie to przyjemność stanowi wyznacznik i ideologię, która kreuje świat konsumentów, a kreowanie radości i szczęścia za wszelką cenę staje się obowiązkiem. Każda jednostka musi być szczęśliwa lub przynajmniej odczuwać taką potrzebę. Coraz częściej szczęście zostaje przełożone na wspomniany wcześniej shopping. Ludzie mają kupować, aby być szczęśliwymi osobami. Osiągnięcie pełni szczęścia nie jest możliwe, ponieważ konsumenta wciąż prowokuje się do posiadania czegoś nowego (nowa funkcja w telefonie, nowy krój, najnowsze wydanie) i zaspokajania kolejnych i kolejnych potrzeb generowanych przez specjalistów od reklamy. Cechą pokoleniową młodzieży jest odwaga, poczucie sprawstwa i panowania nad wieloma rzeczami. Nieobce im jest poczucie kontroli i wpływu na innych. Interesują ich tylko fakty poparte argumentami, które pozwalają iść do przodu. Młodzież wie, że kto posiada

${ }_{12}$ W. Jakubowski, Kultura popularna jako obszar refleksji pedagogicznej, [w:] Edukacyjne konteksty kultury popularnej, red. W. Jakubowski, E. Zierkiewicz, Kraków 2002, s. 19. 
wiedzę w danym zakresie - ten wygrywa i jest w stanie zdominować innych. Coraz częściej młodzi ludzie koncentrują się na sukcesach, niechętnie przyznają się do porażki, pomijają trudne tematy - chcą cieszyć się życiem i patrzeć na nie pozytywnie. Szkoda im czasu na podejmowanie refleksji nad własnym życiem. Liczą się szybkie decyzje, a w razie czego wybór innej drogi. Nie szukają jego sensu, żyjąc tu i teraz tym co ważne w danej chwili. Mając świadomość tych cech pokoleniowych, marki za pomocą mediów i reklamy docierają do nastolatków starając się spełnić ich potrzeby, nie zawsze w sposób uczciwy. Dlatego tak ważna jest edukacja medialna młodzieży, zwrócenie ich uwagi na potrzebę ciągłego rozwijania wiedzy o nowych mediach, nauka krytycznego z nich korzystania i umiejętność dostrzegania manipulacji medialnych, w tym reklamotwórczych. To, czy dadzą się manipulować zależy od ich wiedzy, doświadczenia, ale i osób w ich najbliższym otoczeniu, które zwrócą im uwage na pewne mechanizmy i praktykę kreowania fałszywych wartości przez media i w mediach. Santorski podsumował: „Wygra ten, kto połączy znajomość najnowszych technologii ze światem tradycyjnych wartości"13.

Odbiorcy zacierają linię pomiędzy światem realnym a wykreowanym. Jest to zjawisko niebezpieczne, któremu większość ludzi ulega nieświadomie i daje się wciągać w machinę manipulacji. Dla reklamodawców to bardzo dobra informacja - wiedzą, że konsument jest niedojrzały, infantylny i skupia się na sobie oraz swoich potrzebach ${ }^{14}$. Wprowadza to konsumenta w spiralę, która prowadzi do jego ciągłego nienasycenia i rozczarowania. Pożądane są zarówno dobra duchowe, jak i materialne - czyli tak zwana hiperkonsumpcja. Najczęściej jednak konsument, zwłaszcza ten młody, nie potrafi odróżnić potrzeb właściwych od wykreowanych, sprzedać więc mu można prawie wszystko, tylko trzeba wiedzieć jak. Media są potęgą, jeśli chodzi o kreowanie wartości, dlatego tak ważna jest edukacja konsumenta ${ }^{15}$, o której wspominałam wcześniej.

\section{Materiały i metody}

W 2018 roku przeprowadziłam badania, które objęły młodych konsumentów pomiędzy 16-19. rokiem życia. Przedmiotem tych badań były

${ }^{13}$ J. Morbitzer, W strone przyszłej edukacji medialnej, [w:] Edukacja jutra, t. 2, red. K. Denek, T. Koszyc, W. Starościak, Wrocław 2009, s.69-76.

14 M. Bogunia-Borowska, Infantylizacja kulturowa. Adolescencja dzieci oraz infantylizacja dorostych, [w:] Dziecko w świecie mediów i konsumpcji, red. M. Bogunia-Borowska, Kraków 2006, s. 13-18.

15 M. Snarska, Corporate design - wizualizacja tożsamości, [w:] Kształtowanie wizerunku, red. B. Ociepka, Wrocław 2005, s. 91-98. 
zachowania młodych ludzi oraz ich wybory. Główny problem badawczy został zdefiniowany następująco: Jaka jest świadomość konsumencka młodzieży? Problemy szczegółowe: jakie decyzje konsumenckie podejmuje młodzież? Czy pożądanie produktów ma wpływ na wybory badanej młodzieży? Czy młodzież jest zadowolona z podjętych przez siebie decyzji? Zastosowałam metodę sondażu diagnostycznego, technikę - ankietę. Do moich badań (zwracając uwagę na przedmiot i zakres problematyki) wykorzystałam narzędzie badawcze, jakim jest kwestionariusz ankiety online, w którym posłużyłam się zarówno pytaniami otwartymi oraz pytaniami alternatywnymi. Zapewniłam grupę odbiorów, że ankieta będzie anonimowa i wykorzystana tylko i wyłącznie do celów naukowych. Grupa badawcza została dobrana metodą doboru losowego prostego, z zastosowaniem techniki losowania nieograniczonego. W związku z tym istnieje duże prawdopodobieństwo, że dostosowano ją na zasadzie przypadku. Grupę badaną stanowiła młodzież licealna (licea ogólnokształcące). Wychowawcy klas przesłali ankiety do uczniów. Celowo zostali dobrani uczniowie z różnych roczników - 148 respondentów (78 kobiet i 70 mężczyzn).

Organizując badania, wykonałam następujące czynności: wybrałam grupę biorącą udział w badaniu, określiłam zmienne, dobrałam wskaźniki, przygotowałam narzędzia badawcze (kwestionariusz ankiety online), przeprowadziłam badania na wybranej grupie, zakodowałam wyniki badań, przeprowadziłam analizę wyników badań, nawiązałam do teorii, wykazałam związek teorii z praktyką. W przeprowadzonym badaniu pilotażowym, na podstawie wywiadu z respondentami w podobnym wieku, zostały dobrane produkty pożądane, o które zapytałam w kwestionariuszu: artykuły spożywcze, artykuły odzieżowe, artykuły sportowe, kosmetyki, multimedia i akcesoria.

\section{Rezultat}

Jak już wspomniano, w badaniu wzięło udział 148 licealistów: 78 kobiet $(52,70 \%)$ i 70 mężczyzn (47,30\%). Kobiety chętniej wskazywały kosmetyki, natomiast mężczyźni artykuły sportowe. Pozostałe wybory produktów nie były zależne od płci badanych. Respondenci zostali poproszeni o zaznaczenie, który z determinantów jest dla nich najistotniejszy przy wyborze produktów. Do wyboru otrzymali: cenę, jakość produktu, wygląd opakowania. Następnie ankietowani młodzi konsumenci mieli dobrać jedną cechę do jednego konkretnego produktu. 
Odpowiedzi respondentów

\begin{tabular}{|l|c|c|c|c|c|}
\hline & $\begin{array}{c}\text { Artykuły } \\
\text { spożywcze }\end{array}$ & $\begin{array}{c}\text { Artykuły } \\
\text { odzieżowe }\end{array}$ & $\begin{array}{c}\text { Artykuły } \\
\text { sportowe }\end{array}$ & Kosmetyki & $\begin{array}{c}\text { Multimedia } \\
\text { i akcesoria }\end{array}$ \\
\hline $\begin{array}{l}\text { Cena } \\
\text { produktu }\end{array}$ & $46(31,08 \%)$ & $43(29,05 \%)$ & $23(15,54 \%)$ & $12(8,10 \%)$ & $24(16,21 \%)$ \\
\hline $\begin{array}{l}\text { Jakość } \\
\text { produktu }\end{array}$ & $4(2,70 \%)$ & $34(22,97 \%)$ & $26(17,56 \%)$ & $12(8,10 \%)$ & $78(48,64 \%)$ \\
\hline $\begin{array}{l}\text { Wygląd opa- } \\
\text { kowania }\end{array}$ & $22(14,86 \%)$ & $46(31,08 \%)$ & $32(21,62 \%)$ & $3(2,02 \%)$ & $45(30,40 \%)$ \\
\hline
\end{tabular}

Źródło: badanie własne.

Ponad $1 / 3$ respondentów zwraca uwagę na cenę artykułów spożywczych oraz odzieżowych. Około $20 \%$ wskazało artykuły sportowe oraz multimedia i akcesoria jako te, których cena jest istotna, ale nie najważniejsza. Młodzież najmniej zwraca uwagę na cenę kosmetyków.

Około 50\% ankietowanych wskazało multimedia i akcesoria jako te, które powinny wykazywać się wysoką jakością. Natomiast, artykuły odzieżowe i sportowe są ważne, ale nie najważniejsze. Zaledwie kilka osób podało, że liczy się dla nich jakość kosmetyków, a tym bardziej artykułów spożywczych. Wygląd opakowania ma znaczenie w przypadku artykułów odzieżowych oraz multimediów i akcesoriów. Tę cechę oznaczyło zdecydowanie ponad 30\% osób badanych. Niewiele mniej (ok. 20\%) mają artykuły sportowe. Wygląd artykułów spożywczych i kosmetyków jest istotny w mniejszym stopniu. W kolejnym pytaniu respondenci zostali zapytani, co według nich przekonuje ich najbardziej do zakupu produktu. Młodzież mogła wypowiedzieć się pisemnie. Ponad połowa wypowiedzi odnosiła się do produktów zakupionych, zaobserwowanych lub polecanych w Internecie.

Jestem wielka fanka FitLovers i ogladam ich na YouTube. Teraz wystęuja w Ameryka Express. Sprzedaja super okulary. Teraz to prawie każdy je ma.

Nikt mnie nie przekonuje. Nie wierze w reklamy $w$ Internecie. Sam kupuje co chcę.

Kupuje to co polecaja najlepsi.

W Internecie jest wszystko o czym tylko pomyśle.

Kupuje tylko najlepsze rzeczy. Chcę by byty tadne i modne.

Zaledwie kilka osób wskazało rodzinę i przyjaciół. 12 osób (8,10\%) nie podjęło próby wyjaśnienia, co ich przekonało do zakupu produktu. 
Ostatnie pytanie zadane młodym badanym dotyczyło reklamy w Internecie. Respondenci mieli odpowiedzieć, czy są zadowoleni z produktów, które sami wybierają. W tym przypadku respondenci odpowiadali: tak - 132 $(89,19 \%)$, nie wiem $-12(8,10 \%)$, nie -4 osoby $(2,70 \%)$.

\section{Wnioski z badań. Dyskusja}

Rozważając przeprowadzone badania, możemy wyciągnąć kilka wniosków:

Kobiety w większym stopniu zwracają uwage na środki kosmetyczne. Mężczyźni natomiast wybieraja artykuty sportowe.

Cechy te są zdeterminowane płcią oraz sposobem prezentacji produktów. Z obserwacji wynika, że młode kobiety bardziej dbają o wygląd i uznają te elementy za istotniejsze. Natomiast młodzi mężczyźni chcąc przypodobać się płci przeciwnej, inwestują w sprzęt sportowy, który ma wpłynąć na wzrost ich atrakcyjności u niej lub w celu wzmocnienia swojego poczucia wartości.

Cena produktu jest istotna w przypadku produktów spożywczych.

Młodzi ludzie często artykuły spożywcze mają zapewnione przez rodzinę, z którą mieszkają. Kiedy dysponują własnym budżetem, wolą zainwestować w produkty, które przyniosą im więcej korzyści społecznych.

Jakość multimediów i akcesoriów jest najistotniejsza dla młodych ludzi.

Młodzież zamierza mieć sprzęt dobrej jakości, aby utrzymywać dobrą pozycję w grupie społecznej, jak również by móc kontaktować się z rówieśnikami.

Najmniej istotna dla młodzieży jest jakość produktów spożywczych.

Wynik prawdopodobnie jest związany z sytuacją ekonomiczną młodzieży. Często młodzi ludzie mieszkają jeszcze z rodzicami i własne fundusze przeznaczają na przyjemności spożywcze. Nie są one jednak najważniejsze.

Najistotniejszy jest wygląd artykułów odzieżowych oraz multimediów i akcesoriów.

Produkty te spośród wymienionych są najczęściej widoczne. Młodzież dokonuje oceny poprzez posiadanie konkretnych dóbr materialnych. Niewiele dalej pojawiają się artykuły sportowe.

Najmniej istotny jest wygląd kosmetyków.

Prawdopodobnie łączy się to z tym, że opakowania kosmetyków nie nosimy przy sobie na co dzień. Młodzi ludzie mogą korzystać z kosmetyków, ale niekoniecznie świadczą one o pozycji społecznej. 
Ponad połowa ankietowanych wskazała udział Internetu przy zakupie produktu.

W wielu wypowiedziach pojawiał się Internet jako źródło informacji o produkcie. Badani chcąc się utożsamić z osobami promującymi produkt, sami je zakupują.

Około 90\% respondentów jest zadowolonych z własnych wyborów.

Młodzież czuje się dowartościowana oraz że przynależy do odpowiedniej, wybranej przez siebie grupy.

Badania wykazały, że aby mieć możliwość kontroli wyborów konsumenckich młodzieży, należałoby wejść do świata influencerów. Wyznaczane przez nich trendy są odbierane jako wiarygodne i pozwalają młodzieży poczuć, że przynależą do wybranej przez siebie grupy społecznej. Aby badania te pogłębić, należałoby przeanalizować content (zawartość) oferowaną przez influencerów. Dlatego warto przyjrzeć się produktom przez nich oferowanym, a także sposobom, w jaki to czynią.

Świadomość konsumencka młodzieży istnieje, ale młodzi ludzie sami wyrażają zgodę na docieranie do nich z produktami, które są im oferowane. Świadczy o tym wysokie zadowolenie z posiadanych produktów, które wynosi aż 90\%. Młodych ludzi można łatwo przywiązać do produktu. Wystarczy tylko wsłuchać się $\mathrm{w}$ ich zainteresowania i przez nie docierać do nich z produktami.

\section{BIBLIOGRAFIA}

Bardziejewska M., Brzezińska A., Hejmanowski Sz., Osiagnięcia rozwojowe i zagrożenia dla rozwoju w okresie dorastania, [w:] Dzieci i młodzież wobec agresji i przemocy, red. A. Brzezińska, E. Hornowska, Warszawa 2004.

Bogunia-Borowska M., Infantylizacja kulturowa. Adolescencja dzieci oraz infantylizacja dorostych, [w:] Dziecko w świecie mediów i konsumpcji, red. M. Bogunia-Borowska, Kraków 2006.

Brzezińska A., Spoteczna psychologia rozwoju, Warszawa 2005.

Czarnecka G., Samobójstwo w świetle pogląów na temat rozwoju struktury „ja”, [w:] Młodzież w zmieniającym się świecie, red A. Keplinger, Wrocław 2001.

Ćwikliński A., Pozytywne i negatywne znaczenie mass mediów dla środowiska edukacyjnego uczniów, [w:] Edukacja jutra, t. 2, red. K. Denek, T. Koszyc, W. Starościak, Wrocław 2009.

Dobson J.C., Przygotowanie do dojrzatości, Warszawa 1993.

Doliński D., Psychologiczne mechanizmy reklamy, Gdańsk 2005.

Jakubowski W., Kultura popularna jako obszar refleksji pedagogicznej, [w:] Edukacyjne konteksty kultury popularnej, red. W. Jakubowski, E. Zierkiewicz, Kraków 2002.

Jawłowska A., Reklama jaki przekaz wartości, [w:] Kultura w procesie zmiany, red. A. Jawłowska, G. Woroniecka, Olsztyn 2003.

Kurzępa J., Zagrożona niewinność, Kraków 2007. 
Melchior M., Społeczna tożsamość jednostki (w świetle wywiadów z Polakami pochodzenia żydowskiego w latach 1944-1955), Warszawa 1990.

Melosik Z., Szkudlarek T., Kultura, tożsamość i edukacja - migotanie znaczeń, Kraków 1998.

Morbitzer J., W strone przyszłej edukacji medialnej, [w:] Edukacja jutra, t. 2, red. K. Denek, T. Koszyc, W. Starościak, Wrocław 2009.

Snarska M., Corporate design - wizualizacja tożsamości, [w:] Kształtowanie wizerunku, red. B. Ociepka, Wrocław 2005.

Strelau J., Doliński D., Psychologia, t. 2, Gdańsk 2008.

Zawada A., Reklama a socjalizacja społeczna dzieci i młodzieży, [w:] Media i edukacja w aspekcie globalizacji, red. A.W. Mitos, przy współudziale Z. Gajdzicy, Cieszyn 2003. 